Article

\title{
Translating Carlyle: Ruminating on the Models of Metafiction at the Emergence of an Emersonian Vernacular
}

\author{
David LaRocca \\ Cinema Department, Binghamton University, 4400 Vestal Parkway East, Binghamton, NY 13902, USA; \\ davidlarocca@post.harvard.edu
}

Received: 1 June 2017; Accepted: 28 July 2017; Published: 15 August 2017

\begin{abstract}
Given the exemplary studies of Thomas Carlyle's influence on the Boston intelligentsia of the 1830s and 1840s, for instance by Robert D. Richardson and Barbara L. Packer, we may wonder if there are other questions to ask on the subject-and then, not so much as a point of disagreement or divergence, but rather in a spirit of seeking what may come to light given that so many elemental aspects have been so well digested by others. Avoiding a rehearsal of expert observations, much less a rote re-treading of key insights, I wish to focalize the present investigation by asking how, in particular, a single book—Sartor Resartus_affected Emerson's conception of what might be possible for him to think about literary, religious, and philosophical expression in terms of humor, satire, genre, and translation (specifically cultural translation); thus, I am asking about the interaction between form and content, and specifically how the form and content of Sartor Resartus makes itself known and available to Emerson. Borrowing from George Eliot, the foregoing notes resolve themselves into the query that guides the present investigation: how was reading Sartor Resartus an "epoch in the history of" Emerson's mind?
\end{abstract}

Keywords: Ralph Waldo Emerson; Thomas Carlyle; Sartor Resartus; American Transcendentalism; transcendental thought; translational hermeneutics; metafiction; metaphor; genre; cultural translation

In a late chapter of Thomas Carlyle's Sartor Resartus: The Tailor Retailored (1833-1834), the bilious Teutonic professor Diogenes Teufelsdröckh remarks:

In these distracted times, [ ... ] when the Religious Principle, driven out of most Churches, either lies unseen in the hearts of good men, looking and longing and silently working there towards some new Revelation; or else wanders homeless over the world, like a disembodied soul seeking its terrestrial organization,-into how many strange shapes, of Superstition and Fanaticism, does it not tentatively and errantly cast itself! The higher Enthusiasm of man's nature is for the while without Exponent; yet must continue indestructible, unweariedly active, and work blindly in the great chaotic deep: thus Sect after Sect, and Church after Church, bodies itself forth, and melts again into new metamorphosis (Carlyle 2000, pp. 201-2).

When these words first appeared serialized in Fraser's magazine (between November 1833 and August 1834), a newly thirty-year-old Ralph Waldo Emerson was making his inaugural, and life-altering expedition across Europe, through England—and eventually to Scotland, where he met with the author of Diogenes's observation, Mr. Thomas Carlyle of Craigenputtock, Dumfriesshire. In those "distracted times," the vogue for Americans making the Grand Tour was already in full form, and yet, Emerson coupled a fever for tourism of the Old World with a vocational crisis and a period 
of mourning (his wife, Ellen, died aged nineteen in February 1831). ${ }^{1}$ When we re-read Diogenes's observation with Emerson in mind, the sentences conjures a portrait of our solitary voyager on his way to who knows what.

Since the paragraph from Sartor Resartus paints a fictitious rendering of affairs, one of the tasks ahead would be to suss out Emerson's true proximity to such a portrait—for example, how near or far Emerson is in fact from the characterization Carlyle offers. We could begin by cutting away bits that seem out of place, even erroneous (Emerson, for example, was rarely, if ever, given to "Superstition and Fanaticism" - he was, rather a regular critic of both); yet we may find, in other parts of this passage (and throughout Sartor Resartus more generally) resonance with the young Emerson, as when we hear Carlyle, or better,

Teufelsdröckh postulate: "the Religious Principle, driven out of most Churches, either lies unseen in the hearts of good men, looking and longing and silently working there towards some new Revelation." As such studies must, mine will proceed with caution as well as speculation, testing for promising affinities, but also clear-eyed with a willingness to let supposed harmonies dissolve in the light of contradictory evidence. (We know, for example, that Emerson, even early on in their relationship, was harshly critical of Carlyle's support of slavery and related barbarisms.) My motivation is not to "prove" some kind isomorphic impression of influence from Sartor Resartus onto Emerson, but rather, more tenuously (and therefore, hopefully more defensibly) to appreciate the salient moments when resemblances appear or can be discerned through reading.

In what follows, then, I aim to offer a lengthy gloss on the suggested alignment between this fictional text (in the quotation and more broadly in the work Sartor Resartus) and Emerson's evolving sense of the meaning, purpose, and possibility for his literary, religious, and philosophical expression. As a way of marking out the purview of the following investigation, though, it should be apparent that we are fortunate to have exemplary studies of Thomas Carlyle's influence on Emerson and the broader Boston intelligentsia of the 1830s and 1840s, for instance by Richardson (1995) and Packer (2007). Partly these and other accomplished labors leave us wondering if there remain questions worth asking on the subject. Moving forward here, then, not in disagreement or divergence from such scholarly achievements, but rather in a spirit seeking what may come to light given that so many elemental aspects have been so well digested by others-and wishing to avoid a rehearsal of expert observations already made, much less a rote re-treading of key insights-we may turn, for example, to what may prove to be a productive constellation of topics, in particular, asking: what can be said about humor, satire, genre, and translation (especially understood as cultural or conceptual translation) as they relate to Emerson's reading of Carlyle? It is in a reply to this question-and its areas of interest and concern - that I hope to illuminate how these present, but perhaps still under-theorized, topics may help us think about the presence and effects of Sartor Resartus in the life of Ralph Waldo Emerson at a transitional and transformative moment in his intellectual and writerly life-when, we could say, Emerson was becoming Emerson.

Before he left for Europe, we might condense our description of Emerson's religious commitments as Unitarian; a not insignificant part of his vocational crisis circa 1833-1834 was owing to the fact that he resigned from the Unitarian ministry in the months leading up to his departure for Malta in December 1832. But trying to account for what, for example, becomes of Emerson's religious thinking (and about religion) becomes immensely more complicated—and consequential—when we

1 For more on Emerson's experience as a tourist, see (Habich 2015). For more on the interaction between Emerson's English and European tours and his evolving thought, see (Koch 2012) and (LaRocca 2013a). Acknowledgments: I offer my sincere thanks to a robust and informed group of anonymous readers of an earlier version of the present text, as well as to the editors for their invitation to contribute to this special edition. Furthermore, I am grateful to Emily Apter for her gracious support and crucial remarks on translation offered during her seminar on "Untranslatables" convened at The School of Criticism and Theory at Cornell University in the summer of 2017, and extend my thanks to the director (Hent de Vries), the seminar leaders, and visitors, as well as the participants in Apter's seminar, all of whom formed a remarkably generous and insightful intellectual community. 
follow after him through his tumultuous encounters with the deep history of the European continent (especially up-close encounters with Catholicism) and then England (land of his Puritan ancestors). Moreover, as Emerson "wanders homeless over the world," "work[ing] blindly in the great chaotic deep," he meets artists (Horatio Greenough), poets (Samuel Taylor Coleridge, Walter Savage Landor, William Wordsworth), philosophers (John Stuart Mill), and scientists (Georges Cuvier, Michael Faraday, Richard Owen). By the time he departs Liverpool for Boston in September 1834, he admitted to himself "I like my book about nature [ ... ]" and declares in his journal "I will be a naturalist." (CW ${ }^{2}$. vol. I, p. 399; JMN ${ }^{3}$ vol. IV, p. 200) Religious thinking-whatever its institutional or parochial stripe-seems already dispatched; or has it been converted into a brand of Naturalism? Could Carlyle or his book, Sartor Resartus, have played a role in that shift of claim and circumstance? My query, in the pages to follow, then aims to gain some purchase on the radical transformation we see from a married Unitarian minister to a returning widowed vagabond and ex-minister who delivers a lecture entitled "The Use of Natural History." Since this is an historical narrative-and not the conjuring of a fictional ur-story about the nineteenth century transition from theodicy and eschatology to the age of industrial machines and biological evolution - we may marvel even more at the compactness and intensity of Emerson's journey. Since his transfiguration was not capricious but authentic and indelible, it draws our attention both for its idiosyncrasy and its emblematic status (for his age, and perhaps for our own).

Despite the brief period in which Emerson finds permission to think of philosophical and religious themes and problems "out of school" (and away from the pulpit), there are innumerable influences and encounters that we could profitably train our attention to. (Owing to space constraints-the present article is already fairly long-I leave aside the rich font that is Emerson's Sermons, now in four volumes.) As noted, I have chosen to focalize the present investigation by asking how, in particular, a single book-Sartor Resartus_-affected Emerson's conception of what might be possible for him to think about literary, religious, and philosophical expression in terms of humor, satire, genre, and translation; thus, I am asking about the interaction between form and content, and specifically how the form and content of Sartor Resartus makes itself known and available to Emerson. As with most "influence studies," the degree of immediate impact—much less the prognosis for residual effects—must be tempered by one's own experience as a reader of Carlyle and Emerson, and thus by the particularity of a single attempt, such as mine, here. But I am not alone; there are many worthy and accomplished studies, which I am delighted to rely upon. The point of what follows, then, is not to herald Sartor Resartus as the sole or singular agent of Emerson's imaginative leap from minister to essayist, from Unitarian to Naturalist, but to marvel at the concurrence of time, theme, form, and author (in this case, Carlyle) as they might have been received by a young Emerson eager for orientation: "looking and longing and silently working there towards some new Revelation; [ ... ] like a disembodied soul seeking its terrestrial organization" (Carlyle 2000, p. 201). What I can offer, then, is a series of vignettes and suggestive appositions of texts (by Carlyle, by Emerson) and temperaments (of Carlyle's, of Emerson's), and hope that the accumulated force of such juxtapositions and arrangements proves illuminating - especially about the way these confluences might not simply admit of influence, but more broadly to a meaningful encounter with the emerging thought of Emerson during a critical phase in his intellectual, moral, and spiritual development, namely, in his movement from a representative of the Church in the pulpit to a representative of himself at the lectern.

Much has been made about the early and immediate affection between Carlyle and Emerson, as well as the broader strains and estrangements of their long-term friendship, but I take consolation that even if affiliations prove tenuous (and seasoned scholars assure us the refractions and resemblances are sound and substantive), there is much to learn from the volatile, contested, ever-unresolved relationship between these two contemporary writers. Their connection, whether complementary or

The Complete Works of Ralph Waldo Emerson (Emerson 1903-1904), abbreviation = CW.

The Journals and Miscellaneous Notebooks of Ralph Waldo Emerson (Emerson 1960), abbreviation = JMN. 
combative, is remarkably, endlessly captivating. Part of that fascination derives from the practice and process of assessing a bold and evident, but nevertheless, mercurial correspondence of ideas and styles, forms and postulations that obtain in the works themselves (our focus in the present study) but also, not surprisingly, in the personalities-beyond-the-page. Carlyle and Emerson are bound up with one another, with the latter especially indebted to the former, yet how this sinuous coupling makes itself known (or remains cloaked and obscured) informs any attempt to read their works in tandem. Lines of conjunction and instances of conjugation, in this case, appear to call out for vigilant revision and continuous rethinking - and perhaps that is precisely the legacy such estimable writers deserve.

As a prolegomena-and in and authorial interruption befitting an article on meta-methodologies (from Cervantes to Sterne to Melville) — let me add what could be construed as a disclaimer and even an apologia (in the classical register of a defense), though not presented from having taken offense much less to give it: for those readers who may find my method unsystematic, and my project too modest in its ambitions (and perhaps at the same time immodest in tone), what can I say? I am not writing out of a precious humility, for example, but toward a more openly conversational style-to be frank in the face of terrifically difficult tasks, to seek tuitions to underwrite intuitions, to critically reflect on habits of system-building and theory-making and the presumed promises of tempting teleologies, to be speculative when reasons run aground, to admit defeat, to test out ideas in kindred and cognate disciplines that feel pertinent-if sometimes distant (and thus risk the rebuke of "experts" who police the precincts and borders of such fields). Perhaps we can take a cue from the language of the "collaborative humanities" and "experimental humanities" (and bracket the charged negotiations over multi-, trans-, anti-, or non-disciplinarity). ${ }^{4}$ This is to say, in what follows, I am aiming to sustain and evolve an approach I conducted in a monograph (LaRocca 2013a), an edited volume (LaRocca and Miguel-Alfonso 2015), and in a series of essays and articles undertaken in a similar vein. I have heard some critics pejoratively describe my work as succumbing to an "associative method," as if spirited pattern recognition were a sin-and moreover, an impoverished way of doing serious scholarship and literary critical work; yet, other critics have, nevertheless, invoked the same syntagma as propitious, indeed, regarding it as inherent to the work of theory itself. In fact, one esteemed colleague, has said of such work-without irony-that it "illuminates Emerson's mind by, in effect, pursuing his methods" (LaRocca 2013a). The contrasting assessments leave me wondering about the prospects for a genuine, generative, and lasting reconciliation between traditions, schools of thought (e.g., where post-analytic $=$ post-continental), and thus a true manifestation of the trans- in transdisciplinary research. I will hazard, then, to say that such methodological controversies remind us of various charged apothems offered by Emerson and Thoreau about the who and how of thinking as well as the where and when of it. In their wake, we are called to think about the (necessary) acknowledgment that such work is authored, and thus provisional, and also that any such criticism worthy of the name comes coded with its own ethos; the character of the author and text, as Plato and Aristotle showed us millennia ago, ride together alternately on the horses of thought.

What then of the facility or flaccidity of the "associative method," so called? If I cannot or should not cite Emerson himself on the centrality of analogy to human thinking (e.g., "Nature loves analogies," "man is an analogist," "All thinking is analogizing," from "Education," Nature, and "Poetry and Imagination,") on account of his proximity to the present project, then let me update my references with Douglas Hofstadter and Emmanuel Sander's 570-page tomb, Surfaces and Essences (Hofstadter and Sander 2013), where they aim to convince us to treat "analogy as the fuel and fire of thinking." In part, Hofstadter and Sanders provide some ground-and significant reason-for considering that the thesis (and "thesis-driven") is not the only way to proceed, and instead we might conjure a criticism of the premise. When scholarship is premise-driven, we may heed the

4 Amanda Anderson noted that the Cogut Institute for the Humanities at Brown University now offers a Graduate Certificate in Collaborative Humanities (Anderson 2017). The Draper Program at New York University is now called the Center for Experimental Humanities. 
usefulness of its diagnostic and exploratory capacities, leaving for other occasions the programmatic, the doctrinal, the syllogistic. There is much to mine, likewise, in Philippe Descola's landmark Beyond Nature and Culture, namely, that "analogism" is one of "four basic ontological regimes," and thus very far from a dismissable, ad hoc tic (Descola 2013, p. xiii) ${ }^{5}$. Indeed, when assessing the centrality and fecundity of the approach, Descola describes "the dizzying prospects of analogy" (Descola 2013, pp. 201-31). Meanwhile, some scholars (again, those dubious about the chosen methods) may wish me to tease out "tractable specifics," i.e., to identify how discrete lines of Emerson "came from" which previous thinker or text-as if reading were not an interpretive art (a fundamentally hermeneutical enterprise, indeed, in this respect, a labor of translation), but something more like a word-matching game, concordance-making, algorithm generation, the modeling of matrices, and thus various forms of "pattern recognition, the mastery of large data sets, [and] statistical measures of a world" (Apter 2017); some other scholars, on the contrary, may appreciate the attempt to explore what Carlyle (and other writers) meant to Emerson.

One cannot satisfy all readers, of course, but my hope is that there is room for more than one way of writing scholarly criticism, and that readers used to a prominent and prevailing approach will yet retain a willingness to tolerate mine-and perhaps even, after a generous—call it Arnoldian-reading, find it satisfactory.

\section{The (Unexpected) Significance of Humor and Satire for Transcendentalism}

"No work of Carlyle's better reflects his native genius, or his sense of humour," writes Simon Heffer, "than Sartor" (Heffer 1995, p. 114). And Heffer underscores the point that Carlyle's sense of humor was his "greatest virtue" (Heffer 1995, p. 21). By reading Emerson's work in company with Carlyle's Sartor Resartus, we may be able to assess one prominent way in which Transcendentalism took on its American cast-a form and a content intimately bound up with its relation to and transformation of inherited, institutional religious practice, philosophical principle, and literary means. Carlyle was a bold experimentalist in historical, literary, philosophical, political, and religious terms-attacking the language and the thoughts these forms of expression made possible with the kind of brutal, unflinching audacity that one could associate with the bravest, most skeptical investigations of the natural sciences. While the anatomists and geologists of Europe and England were at work (inadvertently) dismantling the edifice of Western civilization's pride in revealed, divine truth-and replacing it with a rational faith in the scientific method-Carlyle didn't suffer fools gladly. He was an enemy of hypocrisy and cant, a merciless critic of vacuous high-mindedness, and we must not forget, very funny. (Funny in the way Nietzsche is funny: as a philosophical satirist who holds up a mirror so we can see our foolishness, our errors, our contradictory claims and natures. Or, as Emerson said to a similar point, but from within a more somber mood: "Temperament also enters fully into the system of illusions, and shuts us in a prison of glass which we cannot see" ["Experience"]).

Emerson is so often portrayed-and perhaps presents himself-as rigid and serious, but he was, also playful—both formally and in his examples and turns of phrase: "The meal in the firkin; the milk in the pan"; "puss and her tail"; "We fancy men are individuals; so are pumpkins" (from, respectively, "The American Scholar," "Experience," and "Nominalist and Realist"). Meanwhile, Carlyle is regularly figured - or again, figures himself — as a curmudgeon (and this much seems true). For many, the charge of curmudgeon will be calmly endorsed by Carlyle aficionados while the notion that Emerson has a sense of humor-much less an appetite for satire-may prove not a scandal but not entirely forthcoming. Indeed, the two of them were already on the case: in a letter to Emerson in 1838, Carlyle wrote: "I am older in years than you; but in humor I am older by centuries" (CEC, p. 198; 15 November 1838). The literary figures I solicit later on-Cervantes, Defoe, Fielding, Swift, Sterne, et al.—may

5 Originally published as Par-delà Nature et Culture.

6 The Correspondence of Thomas Carlyle and Ralph Waldo Emerson, 1834-1872 (Carlyle and Emerson 1883), abbreviation = CEC. 
be the centuries-old company Carlyle can be figured with, while Emerson, on his newer, American soil has more proximate influences, or must contend with the distillation of ideas that have to cross a wide ocean.

In comparing and contrasting temperaments, though, let me call as a first witness- that philosophic-comic par excellence, Friedrich Nietzsche-an attested fan of both writers, but a lover especially of Emerson's work-who wrote of his American mentor: "Emerson.-Much more enlightened, venturesome, complex, refined than Carlyle; above all, happier [ ... ].-Emerson has that good-natured and brilliant cheerfulness that deters all seriousness" (LaRocca 2013b, p. 284). ${ }^{7}$ Emerson may be happier, but Carlyle is more humorous. (Perhaps it is only when placed in contrast with such a stalwart malcontent as Carlyle that Emerson could earn a reputation for work that "deters all seriousness.") Thus, what is meant to be captured in this quick sketch of temperaments (Emerson's cheerful straight man to Carlyle's dour cut-up) is the humor that can be said to animate the philosophical, literary, and religious vigor of their work. The cliché that comedians are the saddest among us seems apropos if we analogize the truth to say that the satirists are the deepest religious thinkers we may come to know.

In related fashion, we find M. Allen Cunningham say of Thoreau: "The Walden author isn't a misanthrope-just misunderstood." ${ }^{\prime 8}$ Kathryn Schulz's scathing take-down of Thoreau—entitled "Pond Scum" - might be a good place to begin a catalogue of such misapprehensions (Schulz 2015); it is more than a little ironical that Schulz herself is the author of a book about how we misunderstand the world, eschew fallibility, and "get stuck in the feeling of being right" (Schulz 2010, 2011). Meanwhile, David S. Reynolds glosses the point about Thoreau's comic anthropophilia: “[Thoreau's] adaptation of popular humor was an intrinsic element of his self-appointed mission to absorb the language of common Americans and make it the vehicle of uplifting notions about individualism and deliberate living. [ ... ] The humor of Walden is indeed popular humor, but it is popular humor carefully transformed by a philosopher who wishes to salvage both his culture and his culture's favorite images" (Reynolds 1988, pp. 498, 502). Reynolds's book title—Beneath the American Renaissance: The Subversive Imagination in the Age of Emerson and Melville—is conceptually consistent (as subversion is happening "beneath" the surface), but it discounts the way in which the humor, as Cunningham suggests, is on the surface of the text: there for readers to glean, if they only have eyes and ears, hearts and heads to discern it. Of course, perceiving (and retaining an appreciation for) those attributes means having the capacity for a deep reading of the surface. In other words, the American Renaissance (in F. O. Matthiessen's syntagma) is already subversive; if we are going back to look, we are re-viewing what has been lying there in plain sight (but remained hidden) all along. Reynolds himself seems to agree, even as his title (and its tropes) may run counter to the point:

[Thoreau's] strategies for transforming popular humor are much like Emerson's. Humor is itself a mode of detachment and manipulation, but Emerson and Thoreau distinguished themselves by manipulating even popular humor itself to serve their ultimately inspirational ends. They did so chiefly by discovering metaphorical use for humorous images that in popular writings were used literally. In effect, they disarmed grotesque images by converting them into figures of higher truths. They offered stylistic healing to savage humorous language even as they offered spiritual healing to human beings in restless modern society (Reynolds 1988, p. 502).

Reynolds's concluding point may have the most resonance in the line I am following here, namely, that the way in which Emerson (and Carlyle, as well as Thoreau) attend to the care of style-the aesthetic form of their writing (as a literary act) —is as philosophically and religiously consequential as any specific content they might address. Thus "stylistic healing" is a euphemism for being on guard for the

7 See also (Hodge 2005, pp. 83-105; LaRocca 2017b, pp. 211-30).

8 See (Cunningham 2016). 
deceptions of dogma, principally, falling in love with the literal expression of an idea or tenet; "stylistic healing" animates the language, and unsettles its appearance of completeness. We could do worse than cite Emerson himself on this point: "People wish to be settled; only so far as they are unsettled is there any hope for them" ("Circles"). If we stopped here, there may be a case to be made for Emerson \& Co. to be forwarding a kind of deconstructive reading of language. Nietzsche was a committed, lifelong reader of Emerson, and later, Heidegger of Nietzsche, and Derrida of Heidegger-so the postmodern tradition may begin earlier than we think (see Hodge 2005; LaRocca 2017b). ${ }^{9}$ But it is Reynolds's second, concomitant notion- "spiritual healing" - that lures us to think we have not yet made the linguistic or deconstructive turn. With Emerson \& Co., after Reynolds, we are encouraged to recognize the way in which stylistics is spiritual Cassin as much as any purported content that identifies spiritual topoi).

If we can trace a line back from Derrida to Heidegger to Nietzsche to Emerson, let us take a cue from such (usefully) "regressive" reading, and begin with Emerson reading "backwards" to Carlyle (of course), but also to Carlyle's reading of Jonathan Swift, and by turns Henry Fielding, Lawrence Sterne, and Daniel Defoe. As a reader might already know, or guess, Carlyle's Sartor Resartus - because of its pedigree in this line of satirists and formal innovators-was a signal influence on Herman Melville during the composition of Moby-Dick, and likewise Walt Whitman for Song of Myself (Carlyle [1987] 2008, p. vii; see also Matterson 2014). "Articles on the influence of Sartor Resartus upon [Charles] Dickens are too numerous to mention," notes Rodger L. Tarr (Carlyle 2000, p. xxviii, n 11). When George Eliot came to assess Carlyle's relevance to his times, in October 1855, and thus to her own, she remarked unequivocally:

For there is hardly a superior or active mind of this generation that has not been modified by Carlyle's writings; there has hardly been an English book written for the last ten or twelve years that would not have been different if Carlyle had not lived. The character of his influence is best seen in the fact that many of the men who have the least agreement with his opinions are those to whom the reading of Sartor Resartus was an epoch in the history of their minds. The extent of his influence may be best seen in the fact that ideas which were startling novelties when he first wrote them are now become commonplaces. And we think few men will be found to say that this influence on the whole has not been for good (Eliot 1908, p. 311).

For herself, Eliot remarked after reading Carlyle's Life of Sterling: "There are racy bits of description in his best manner, and exquisite touches of feeling" (Eliot 1908, p. vii). With this assessment of her own reading, Eliot captures some indication why reading Carlyle would be "an epoch in the history their minds"-for Carlyle coupled stylistics ("his best manner") with affect ("feeling," or what Reynolds above referred to as a "spiritual" dimension).

While Carlyle himself referred to Sartor Resartus as "a kind of didactic novel," Simon Heffer points out that the book "was to have profound religious influence; as a vehicle for Carlyle's sub-Goethean, transcendentalist, post-Christian creed it was read avidly by the circle of Matthew Arnold, Arthur Hugh Clough and [James] Froude in the Oxford of the 1840s. Carlyle took a consciously religious approach to the book" and in the work we can detect "the numerous rhetorical allusions to the Bible, [...] though the smell of the Old Testament pervades all his writings" (Carlyle and Carlyle 1970, vol. VI, p. 396; Heffer 1995, p. 114).

9 As we can, after Cavell, explore the passages and permutations of influence from Emerson to Nietzsche to Heidegger and then back to American shores in the mid-twentieth century (e.g., by the labor of translation and rehabilitation offered by Walter Kaufmann as well as the many readers of Heidegger, such as Derrida, who find an intellectual home in the United States), so we discover a parallel case to explore with Thoreau, namely, the way in which Tolstoy read Thoreau, and Gandhi read Tolstoy, and then Martin Luther King, Jr. read Gandhi-thus closing the loop once again where we encounter Thoreau back on American soil after his translation to Russia and India. 
Influence studies are tricky if only because they are (also) origin stories (and thus, likely, myths), endlessly leading us back and back and back-no doubt with murky interstitial distortions of interpretation laid up prominently in that ever-receding series. Thus, we might identify "novelties" in Emerson that were, in fact, a function of his reading of Carlyle-or for that matter anyone else, from Plato to Plutarch to Plotinus. And therefore such "novelties" could be re-read as commonplaces. Nietzsche's übermensch finds an antecedent in Emerson's Over-Soul, which finds its source in Plotinus, and earlier still in Plato, and then, we might as well look to Pythagoras. As Emerson himself remarked: "When we are praising Plato, it seems we are praising quotations from Solon, and Sophron, and Philolaus. Be it so. Every book is a quotation [ . . ]" (EL $L^{10}$, p. 634). As usual, Emerson was there before us pointing such things out, as he would also admit, prior sholars did the same for him.

Part of our look to the (possible) links between humor and philosophico-religious insight by literary means would seem to require what Kerry McSweeney and Peter Sabor describe as a "process of defamiliarization." We need to estrange ourselves a bit from our habits of, and the history of, reading Sartor Resartus (and perhaps Emerson's work as well) (Carlyle [1987] 2008, p. viii). As part of that initiative, McSweeney and Sabor direct us to regard the book as "essentially a work of imaginative fiction," and therefore keeping better (more fitting) company with the likes of Brontë's Wuthering Heights, Melville's Moby-Dick, Dostoevsky's Notes from the Underground, and Nietzsche's Thus Spake Zarathustra-than the usual literary kith and kin such as Newman's Apologia Pro Vita Sua, Arnold's Culture and Anarchy, Ruskin's Unto this Last, and even other works by Carlyle, such as Past and Present and On Heroes and Hero-Worship (Carlyle [1987] 2008, p. ix). In terms of shared traits, McSweeney and Sabor say of Sartor Resartus and Moby-Dick, for example, that "both works employ uncertain self-conscious narrators who are energetically and sometimes comically attempting to discover coherence and meaning in their material and to say something important about ultimate issues" (Carlyle [1987] 2008, p. ix). As with Sartor Resartus, much hangs on the estimation of Melville's masterwork as being "sometimes" comical, for how, and how much, and when Melville is being comic or satiric or antic or philosophic or literary or mystic or all-six-and-more-simultaneously is a major preoccupation of readers and critics.

If after McSweeney and Sabor, as part of our process of defamiliarization, we turn to Carlyle to think through varying degrees of self-consciousness and humor in Melville, let us do the same for Carlyle (as we will, in time, for Emerson as a reader of Carlyle), and recover texts that shaped his thinking on the way to writing Sartor Resartus. Though we learn that Carlyle's Calvinist house was devoid of imaginative fiction, his years at boarding school afforded him access to Defoe, Fielding, Scott, Smollett, Sterne, and Swift. In his late twenties, when Carlyle (like Emerson) was suffering a crisis of vocation, McSweeney and Sabor tell us his ambition turned to the writing of prose fiction, in significant measure from his reading of Goethe and Schiller-providing startling models of what could be done formally with letters and what ideas and imaginative worlds could be made possible through them. Indeed, at this point, we could ask if one of those "imaginative worlds" could be our own, such that Emerson found it possible to draw on literary techniques (including the creative presumptions and possibilities of fiction) to write about the world as he saw it. We need not slip into some crisis of solipsism and skepticism ("scene-painting and counterfeit," "Life itself is a bubble and a skepticism, and a sleep within a sleep," "Dream delivers us to dream and there is no end to illusion," all from "Experience") to appreciate the way such an idea-i.e., of a creating a world-would be deeply appealing and potentially liberating to a young writer. Indeed, it's not for nothing that Carlyle himself had recognized this for himself, and his own work: he praised fiction as "superior to history for the revelation of truth" (Carlyle [1987] 2008, p. x). Before we even get to the choice of genre-or the use of satire, humor, irony-such a commitment seems to ratify the seriousness of Carlyle's enterprise in Sartor Resartus, his only completed and published book of imaginative fiction. Though it was Goethe's

10 Essays and Lectures (Emerson 1983), abbreviation $=E L$. 
model that provoked Carlyle into the labors (and rewards) of fiction, it is worth noting, as McSweeney and Sabor put it, "how uncongenial Carlyle found Goethe's patient accumulation of realistic detail" (Carlyle [1987] 2008, p. xi).

As early as 1822, when he was twenty-seven, Carlyle wrote to his newlywedded wife, Jane, about a novel he was planning in which the protagonist would speak "not in the puling Lake-style-but with a tongue of fire-sharp, sarcastic, apparently unfeeling, yet all the while betokening to the quick-sighted a mind of lofty thoughts and generous affections smarting under the torment of its own overnobleness, and ready to break in pieces by the force of its own energies." (Carlyle [1886] 1976, p. 137). This proposed novel didn't materialize, but how much of Teufelsdröckh—conceived a decade later—can we recognize in the description? (Meanwhile, as we develop a reply, we might also appreciate a difference in tastes, namely, that Emerson was quite fond of that "puling Lake-style." After all, Emerson had Wordsworth and Coleridge on his shortlist of persons to visit on his first voyage to England-his disappointments with meeting the men notwithstanding his enduring appreciation for their literary-poetic achievements.)

When Carlyle finds the work that would become Sartor Resartus coming into being in the early 1830s, when he still lived in Craigenputtock (before heading south to London, where he would spend the balance of his years), he describes it to his brother, John, as "a strange satirical frenzy" (October 1830); one must wonder why a similar frenzy for imaginative fiction didn't strike him again, after he had moved away from Scotland; and how sad, then, that " $[\mathrm{t}] \mathrm{o}$ the end of his life he never ceased considering the Craigenputtock years the happiest years he had ever spent" (Tennyson 1965, p. 17). We have, then, an imagined world—or as contemporary parlance might put it, an alternate universe-in which Carlyle spends many happy years, indeed decades, writing metafiction from the wilds of Scotland (joining the ranks of Swift et al.), instead of the world we do inhabit where he became a dyspeptic doyen of social and political histories, writing in an airless, sound-proof garret in Chelsea.

As a mark of his temperament-again, how much like or unlike Teufelsdröckh?-we could dwell on the way the first version of the project Teufelsdreck was rejected by Fraser's. Instead of abandoning the implications of the disparaged work, Carlyle digs deeper and resolves to make the piece into a book. And as the manuscript was becoming a book, we can glean much from a third title he had considered: Thoughts on Clothes; or, The Life and Opinions of Herr. Diogenes Teufelsdröckh, Doctor of Universal Jurisprudence. The allusion is perhaps too facile to note, but it is, of course, to Sterne's The Life and Opinions of Tristram Shandy (1760-1767). As notes were made above by McSweeney and Sabor about the allegiances between Sartor Resartus and other works (avant la lettre, viz., Moby-Dick, etc.), they make profitable comparisons with Sterne's book: "Both Tristram Shandy and Sartor are fictions concerned with the making of biographies; both are steeped in the tradition of learned wit, deriving from Rabelais and Cervantes; and both provide dazzling displays of linguistic inventiveness, making frequent use of neologisms and borrowings from a variety of languages." And perhaps, most pertinent to the query underway here, both works "are, at least in part, playful works" (Carlyle [1987] 2008, p. xiv). Drawing in Rabelais and Cervantes enriches the company and thus the context for our thinking here. Indeed, Cervantes was already knee-deep in metafiction a century and a half before Sterne. Yet, it was to Sterne that Carlyle had fixed his proximate attention, in part we must assume, because he esteemed him "our best, our finest, if not our strongest specimen of humour." (Carlyle 1904, p. 17).

Yet, if Carlyle (1836) not only alludes to Sterne's seminal work, he also quotes from Tristram Shandy and engages the text directly (e.g., in Book I, Ch. 9, Adamitism). Yet, there is another kindred and conspicuous precursor to Tristram Shandy that informs (and haunts) Sartor Resartus, and that is Jonathan Swift's A Tale of a Tub (1704). It is Swift who provides the dominating trope of Sartor Resartus: clothes (see LaRocca 2015b, 2015c). But, of course, as we keep tripping over antecedents, we would be remiss to fail noting how the trope is familiar from antiquity, as Nickolas Pappas has wonderfully articulated in his The Philosopher's New Clothes: The Theaetetus, the Academy, and Philosophy's Turn Against 
Fashion (Pappas 2016). ${ }^{11}$ Swift's chosen symbol—the tub—is all the funnier when we remember that the namesake of Carlyle's story is none other than Diogenes of Sinope, a philosopher who famously lived in the nude, a choice that, in Pappas' account, might qualify as a bit of "anti-fashion." Reading A Tale of $a$ Tub after familiarity with Sartor Resartus, we seem to encounter-especially in Section II-a veritable miniaturization (how fitting) of Carlyle's more grandly realized vision. In a beautifully wrought digression, Swift tells us how "a sect arose" whose adherents "worshipped a sort of idol"—in this case, a tailor (Swift [1704] 1986, p. 35). And what were the tenets of this mystico-religious group? "They held the universe to be a large suit of clothes, which invests everything [...]" (Swift [1704] 1986, p. 36).

Look on this globe of earth, you will find it to be a very complete and fashionable dress. What is that which some call land, but a fine coat faced with green? or the sea, but a waistcoat of water-tabby? Proceed to the particular works of the creation, you will find how curious Journeyman Nature hath been, to trim up the vegetable beaux; observe how sparkish a periwig adorns the head of a beech, and what a fine doublet of white satin is worn by the birch. To conclude from all, what is man himself but a micro-coat, or rather a complete suit of clothes with all its trimmings? (Swift [1704] 1986, p. 36).

Once the gimmick is pointed out, it is hard not to see everything after Swift's imagined "fashion" (including the charming puns, among them: in-vests). Carlyle, clearly, was smitten by Swift's depiction of this world and perhaps felt that he had-in such phrases, and according to such principlesan invitation and a mandate for creating a larger work that spun out the theme in new dimensions. Yet, there are even keener resemblances to Sartor Resartus when Swift pushes the clothes metaphor into mystico-religio-philosophical territory, and we can catch a first glimpse of the way Carlyle will innovate beyond Swift's "system of religion" —in effect, weaving and embroidering in Sartor Resartus an even more elaborate "clothes philosophy."

These postulata being admitted, it will follow in due course of reasoning that those beings which the world calls improperly suits of clothes are in reality the most refined species of animals; or to proceed higher, that they are rational creatures, or men. [ ... ] 'Tis true indeed, that these animals which are vulgarly called suits of clothes, or dresses, do, according to certain compositions, receive different appellations. If one of them be trimmed up with a gold chain, and a red gown, and a white rod, and a great horse, it is called a Lord Mayor; if certain ermines and furs be placed in a certain position we style them a Judge; and so an apt conjunction of lawn and black satin we entitle a Bishop.

Others of these professors, though agreeing in the main system, were yet more refined upon certain branches of it, and held that man was an animal compounded of two dresses, the natural and the celestial suit, which were the body and the soul; that the soul was the outward, and the body the inward clothing; that the latter was ex traduce ${ }^{12}$ but the former of daily creation and circumfusion. [ ... ] Besides, said they, separate these two, and you will find the body to be only a senseless unsavoury carcass. By all which it is manifest that the outward dress must needs be the soul (Swift [1704] 1986, pp. 36-37).

Though there are ample affinities worth exploring between Swift's text and Carlyle's reconfiguration and expansion of its imagery, the most pertinent here are, first, that (as McSweeney and Sabor put it) "in Sartor Resartus, the clothing fashioned by society and by religious institutions must be removed and replaced entirely" - hence the tailor re-tailored (or, in another variation, "the patching of the tailor"

11 Another crucial intervention on clothes philosophy comes from Stephen Matterson, who takes up Emerson's contemporary, Herman Melville. In Melville: Fashioning Modernity (Matterson 2014), Matterson develops a comprehensive and compelling account of Melville's encounters with Carlyle, especially Sartor Resartus.

12 Ex traduce. "Transmitted by propagation." As Angus Ross and David Woolley tell us: "theologians disputed whether the soul was derived from the parents like the body (traduction), or whether a new soul was created at each birth" (Swift [1704] 1986, p. 209). 
(Heffer 1995, p. 115)); but secondly, the we discover a "contrast between the descendentalist Swift and the transcendentalist Carlyle" (Carlyle [1987] 2008, p. xv). If we are tracing lines of affiliation and influence, this second point drives to the heart of what Carlyle generally, and Sartor Resartus in particular, might have made available to Emerson during a particularly volatile and formative period in his intellectual, emotional and religious life-namely, in that remarkable (because intense and brief) span in which Emerson translates the language of the Unitarian Church (a native language for him and his family, his ancestors) into the language of Natural History (a new and evolving language very much of his own time-and emphasized as contemporary by his first-hand meetings with some of the leading lights of nineteenth century science: Georges Cuvier, Michael Faraday, Richard Owen, et al.). It is precisely Emerson's composite "languaging" of ideas drawn from religion, natural science, literature, and philosophy that gives rise to what I have called (in the subtitle) an Emersonian vernacular-that is, the particular diction, phrasing, tone, topic, structure, syntax, and style that are now emblematic of the identity of his work and its legacy. The distinctiveness of Emerson's intellectual grammar, his willingness, for example, to borrow and adapt from (seemingly) heterogeneous realms of experience, make us wonder about the development of this vernacular; it does not arise ex nihilo but by way of Emerson's broad reading and acquisitiveness acumen. Rodger Tarr underscores the impact—and my own suspicions for Emerson's consequential reading of Carlyle and the latter's influence on him-by noting that "the early work of Emerson cannot be properly read without the knowledge that Sartor Resartus was its spiritual and linguistic foundation. Divinity School Address would be different if not for Carlyle's call for the new mythus. Nature if not for Carlyle's appeal for a new social fabric, and 'The Over-Soul' if not for Carlyle's clothes philosophy." And Tarr concludes, using the metaphor of "translation" I have been employing: "Emerson was Carlyle's most prominent translator, a gift of considerable circumstance in the light of the dancing iridescence of Sartor Resartus" (Carlyle [1987] 2008, pp. xxxi-xxxii; see also LaRocca and Miguel-Alfonso 2015).

Let us take up Tarr's remarkable claim that "Emerson was Carlyle's most prominent translator." Prominence, we can be sure, does not also (always) mean the premier or best. Read this way, Emerson's fame would get more credit for "translation" than Emerson's capacity to read and be influenced by Carlyle. Yet still more intriguing is the very notion of translation since, after all, Carlyle wrote in English, as did Emerson, though some readers of Sartor Resartus may be forgiven for thinking it is written in a language other than English-the neologisms and literary inventiveness of the text, which makes it regularly difficult to read, also provide the basis for a rich resource of humor (through pun, allusion, metalepsis; and by the juxtaposition of the Editor's parataxis and the German philosopher's prolixity). Tarr provides the occasion for a most generative question, namely: in what way can we speak sensibly about monolinguistic translation? Translation may suddenly be rendered (or reduced) to a (mere) metaphor. Or, if we can maintain a sense of translation's lively, literal reality in the passage of ideas from English to English, then we may yield a finer sense of what Emerson found so appealing about Sartor Resartus, and what he was able to do with his favorable impressions. Thus, we can reflect on the matter-or meaning — of literal (or, better, linguistic) translation as it relates to Emerson's power and capacity to inherit and transform what he read by Carlyle.

\section{Transnational, Transcendental, Translation, Transformation}

As a point of embarkation on the question of translating Carlyle (from, as it were, English to English), consider how comparativists - especially of languages-rightfully assume that the invocation of "translation" is necessarily linguistic in nature. Thus, we are intrigued by the "crossings" of a syntagma such as "there is" when we find it as il y $a$, or es gibt (or from within the same language, where es gibt relates to Da-sein). We must also be on guard for "false friends"-where similar (or even identical) homophonic or graphic traits can lead to error, and no doubt to the (threatening) inversion or deferral of truth in translation (on this point, see Emily Emily Apter's apt "Lexilalia" 2015). If we are in the vicinity of a discussion that explores "what is means 'to philosophize' in translation," we are also already immersed in a context that asks "how to translate the untranslatable" (Apter 2015, p. 160). 
Apter's assessment of Barbara Cassin's Vocabulaire européen des philosophies: Dictionairre des intraduisibles (Cassin et al. 2014), may find kinship with notes Derrida made about that which resists translation: "it is always difficult to read what does not let itself be translated" (Derrida 2002, p. 17). We can appreciate the agency given over to the text itself-as if it were recalcitrant, as if the work of translation were not (solely) a matter of the talent and perspicacity of the translator. Cassin describes her project this way: it "does not pretend to offer 'the' perfect translation to any untranslatable, rather, it clarifies the contradictions and places them face-to-face and in reflection; it is a pluralist and comparative work in its non-enclosing gesture, rather more Borgesian or Oulipian - 'the modern form of fantasy is erudition' Borges tells us-than destinal and heideggerian [sic.]" (Cassin 2010, p. 18). Translation, on this view, is not teleological but rhizomatic.

Now, to be sure, there is a cultural context to the broad(er) labor of translation (as it has been undertaken in the West)-for example, in the so-called tradition of a "metaphysics of presence," (phal)logocentrism, or the Occidental attention to ontologies and phenomenologies of Being-but the work of linguistic translation gives the impression of success: namely, that an idea has "carried over" [trans] from one linguistic home to another. Yet, a reader of a bilingual edition of a given text, a reader familiar with both languages, will find places to quarrel-for example, occasions when the translation is infelicitous, when it fails to make the passage over. Perhaps something has been left behind, and perhaps more troublingly, something new - an error, a distortion-has been introduced. Translation is a not a "pure" science; it may be productive, then, to replace the trope (in Austinian terms) of linguistic "misfiring" with the biochemical image of contamination, for, after all, translation does not have a "target" to hit so much as a present us with a solution whose identity we are charged with characterizing. On this reading, the work of translation involves an analysis (and comparison) of the content of concepts.

With this accumulation of propositions, it may be advantageous to prepare, if not confirm, some linkages between what I am calling cultural (or conceptual) translation with aspects of hermeneutics. As Heidegger's work may fall under "transcendental" and/or "ontological hermeneutics" and Derrida's a kind of "radical" or deconstructive hermeneutics, then it can seem we are in need of a modifier of our own-perhaps something like translational hermeneutics. Why is this not a redundant coupling of terms? For one thing, it marks out the intent to follow after the movement of ideas from one topos to another. The figure of Hermes seems especially pertinent at this point, since, with winged feet, we are aiming to keep pace with the migration of concepts (the "message") from one "place" to another (postulated either as a literal territory, say Scotland or England, a fatherland; or a linguistic one- the home of one's language, a mother tongue). Translational hermeneutics might be glossed as a way of attending to the metaphysics of metaphor: in short, asking after the peculiar, rather uncanny (and not always successful), manner in which ideas-often in the form of tropes and figurative language-make their way from one location to another. Indeed, as the Greek origins of the word remind us, there is a fecund literalism in 'metaphor' itself: that it is about movement or (as contemporary buses in Greece remind us: transit). Metaphors are modes of conveyance; they propel not just thought but make thought into a propellant force. As David Punter has put it, "thinking of one thing in terms of another" is a constitutive mode of human cognition, and this activity is fundamentally "a process of translation" (Punter 2007, p. 13; see also LaRocca 2013a, pp. 155-56).

As the subject head of this section is meant to invoke, I am intrigued by the monolingualism of our chosen texts- that is, our attention is on a form of translation of the transcendental (from Carlyle to Emerson, say), but also, from one country to another (stirring reflection on the transnational potential for such a transmission of ideas). It seems we have grown used to thinking that reading the same language (say, one's native language) does not demand translation. But it does. Still, we may wish to reserve translation as a term of art for the agent whose business it is to enact a passage from one language to another (different) language. We need, then, a way of thinking about translation that happens at the level of reading in one's own language. Perhaps we can call this cultural translation, or find a variant that does the work we need. 
Cultural translation, however, does not provide a prophylactic against error, distortion, or contamination. Just because one reads in English and writes in English is no guard against "mistranslation." (Indeed, what is the difference between "mistranslation" — either literally or figuratively—and inaccurate interpretation?) Of course, mistranslation, in the present context, is not just a borrowed term, but also embodies a pejorative sentiment (since error, accident, and even improvisation are anathema to "serious" scholarship). If Emerson has misunderstood Carlyle on the model of "mistranslation," then we are prone to conclude he has failed in some way. Yet, if we think of cultural translation as a process or practice of interpretation, then we are freed at once from the negative connotations and the sense that there is a standard against which we are judging attempts at, say, transnational inheritance. Indeed, it may be the "errors" (and accidents and improvisations) that draw our greatest interest, and provide the best occasions for understanding a given relation-or passage of ideas from one scene of script to another.

The very conjecture of "mistranslation" and "errors," draws us back, again, to the productive notion of "untranslatabilty" developed by Barbara Cassin, Emily Apter, and others (Cassin 2010; Apter 2013, 2015; Cassin et al. 2014). Are there ideas that cannot "carry over" from one place to another; does a given topos reject the imposition of a foreign notion? In this regard, one thinks too of Jean-Luc Nancy's peregrination on l'intrus (the intruder): "In me there is the intrus, and I become foreign to myself" (Nancy 2008, p. 9). Emerson's pregnant "for the inmost in due time becomes the outmost" is chastened by the countermanding forces of translation, namely, that reverse the process-where, the outmost, in due time, become the inmost ("Self-Reliance"). We are invaded. But at what scale? As Emerson glosses a few years later: "Certain ideas are in the air" ("Fate").

These critical reflections from Cassin—and others such as Apter, Derrida, and Nancy-figure precisely the "philosophizing in languages" that she postulates and heralds (Cassin 2010, p. 17). Yet Cassin, to be sure, has in mind the translation from one language to/from another (different) language; what can we make of these movements (or moments) of mistranslation from within the home of a given language? From English to English? Perhaps we can take up Nancy's postulation that the intruder is already present within us-or in this case, within our own (fittingly, but problematically, "native") language. First, we feel justified in marveling over the distance and difference that may yet obtain between Emerson's and Carlyle's work (though housed in the shared space of English); secondly, we receive a new degree of license to explore-indeed, an obligation to question - that tracing influence can happen successfully at the level of the sentence or even the word. For instance, does "transcendental" mean the same thing in Carlyle as Emerson? In an Arnoldian sense, do they share an "object" of thought-a conception of a work or word "as in itself it really is" (Arnold 1895, p. 3)? Since we are encouraged by mere odds to say "no," we can simultaneously catch a glimpse of the way certain elements of or in Carlyle's prose will remain untranslatable into Emerson's work; in this context, there remains a perplexing double sense of such untranslatability: that Emerson was in a position to (in a Bloomian mood) "misread" his author, but also, and again perhaps also with Bloom in mind, we are-and must—-preside over an operation of translation (from Carlyle to Emerson, and maybe back again) that will risk our own misreadings (Bloom 1975) of the texts these authors have provided to posterity, for us.

Learning a bit about Emerson's own relationship to non-English languages, it appears as something of a fortunate accident (for him) that Carlyle wrote in English-even if Carlyle was, in some sense, offering a reading of German philosophy, especially that of Kant and Schiller-since, as Robert D. Richardson noted: Emerson "hated having to read in the original if a translation was available" (Richardson 1995, p. 222). Would we scold Emerson for lacking an interest, much less an aptitude, for reading in other tongues? Cannot a robust practice of "comparative literature" involve the reading of works in the same language but from different hands? Even of different media (e.g., comparing, as Emerson would do with confidence, a dramatic work from Greek or Roman antiquity and a subsequent painting or sculpture that relied on the earlier account as its model)? Can we not agree that intellectual honesty encourages us to believe that there are myriad sorts of scholarly pursuits to be undertaken, and thus that a division of labor is advantageous, attractive, and not worthy of shame-even if we readily 
acknowledge that there are gifted scholars who are capable of both artful (linguistic) translations and skillful (conceptual) translations? These questions strike at the heart of Emerson's own talents for aggregation and application; as he says of Plato, we can say of Emerson's reading of "foreign" works in English-"He ground them all into paint" ("Plato; or, the Philosopher").

We know of course that Emerson read Goethe in German, and translated Dante's Vita Nuova from the Italian, but we must wonder about the intentions of those who would condescend to a reliance on the hard work and skills of philologists, linguists, and language translators. If you fluently speak and read French or German, do you also speak and read Chinese, Sanskrit, Swedish, and Yoruba? -And if not the latter set, should a reader and scholar be estranged from commenting on Confucius, the Upanishads, Swedenborg, and Fagunwa's The Forest of a Thousand Demons? With Carlyle we do not have to contend with the issue of literal translation, and yet its presence as a problem for interpretation recurs when we address Emerson's reading of, for example, texts written in Hebrew, or those arriving from the Persian poets (especially Hafiz and Saadi), or from the Hindu tradition, or from China (for more on these issues, see LaRocca and Miguel-Alfonso 2015). Richardson notes that, at Harvard, Emerson "took the same set of required courses everyone else did. He learned enough Greek to read both the Iliad and the New Testament," and yet once the coursework ended, and as English translations proliferated in antebellum America, so did the apparent need to be one's own translator (p. 7). As Welt-literatur, in Goethe's phrase, came into prominence when Emerson was a child, we can marvel anew at the role literal translation has played in the dissemination of ideas; but here, after Lawrence Buell, we might describe what Emerson accomplishes in reading Sartor Resartus as something more akin to cultural or conceptual translation (as explicated above, and aligned with what may be profitably named translational hermeneutics)—or perhaps, even better in this specific case, metaphysical translation: from the Germans (Kant, Goethe, Schelling, et al.) through Carlyle and onward to Emerson (Buell 2003, p. 190; and again, LaRocca and Miguel-Alfonso 2015; plus LaRocca 2017b).

To draw from related, familiar territory, look to Thoreau's early paragraphs in the "Reading" chapter of Walden to siphon his sense of our reading in "foreign" works of literature and philosophy—for "in dealing with the truth we are immortal" (Thoreau [1854] 1991, p. 82). That is to say, a reader of Homer in ancient Greek is not in "danger of dissipation and luxuriousness" because such access (to the "original") does not guarantee that wisdom will be gleaned from it (p. 82). The same holds for the translations:

The heroic books, even if printed in the character of our mother tongue, will always be in a language dead to degenerate times; and we must laboriously seek the meaning of each word and line, conjecturing a larger sense than common use permits out of what wisdom and valor and generosity we have. The modern cheap and fertile press, with all its translations, has done little to bring us nearer to the heroic writers of antiquity. They seem as solitary, and the letter in which they are printed as rare and curious, as ever (p. 83).

Thoreau, of course, retains a nostalgia for the ancient, original mother tongues, and commends us-as readers-that learning them "is worth the expense of youthful days and costly hours," that is, even "if you learn only some words of an ancient language [ ... ]" (p. 83). Yet, as the display quotation above shows, the "perpetual suggestions and provocations" yielded by familiarity with the mother tongue (whether it be Greek or English) are not guaranteed. In short, there are labors attendant to both enterprises of reading (viz., in the ancient mother tongues and in the "cheap and fertile press, with all its translations" in our mother tongue, English); we should not begrudge either domain, but find our way to what insights we can discern, by what talents we can muster.

Formally, it is easier to identify the way-and the what—of Emerson's prose as tied to the essayists of Western civilization (from Seneca to Montaigne), or to the aphorists (from Epictetus and Aurelius to Pascal and La Rochefoucauld), but in terms of the conceptual moves necessary to translate-however we are understanding this term, in this context-religious thinking into a thinking compatible with science, Carlyle (and Sartor Resartus especially) provides a much more lucid and productive comparison than the more ready-to-hand pairings of the just-mentioned aphorists, essayists, and (literary) moralists. 


\section{Contemplating Carlyle's Emancipatory Model of Metafiction for Emerson's Literary-Philosophico- Religious Thinking}

While most of Sartor Resartus could be mined for intriguing relationships with Emerson's thinking in the 1830s and beyond, there are particular hot-spots of especial significance. Among others, I can point to specific chapters in Carlyle's work: "Pure Reason," "Symbols," and most emphatically, "Natural Supernaturalism." ${ }^{13}$ It is a measure of one's own reading and interpretation of the blended transition from, say, the Unitarianism of William Ellery Channing to the Transcendentalism of Emerson and his circle, that the culmination of this shift might be described by Carlyle's playful, paradoxical "Natural Supernaturalism." For a trace of resemblance and resonance, look to Emerson in "Circles" where the two realms come together: "I am God in nature; I am a weed by the wall." The parallelism is comedy, surely, but more than that too. We may have reason to count it Emerson's bid for his own brand of Romantic irony. The juxtaposition implies not just analogy but equivalence: that we account the immediacy of terrestrially life with some of the grandeur of the transcendental realm. Oddly, we humans have eagerly fostered the habit of exalting precisely what we cannot perceive, while ignoring the virtues and values of what lies in hand-as Emerson said elsewhere, in a sequence familiar to the work of Stanley Cavell: we remain vexed by the near, the common, the low, the everyday, the ordinary (see Cavell 2003).

If we are confident that we have a sense of what we mean by "Natural"-terrestrial, or even celestial, but governed by laws beyond human whim and imagination-we may approach the second term (viz., supernaturalism) as a bit of a pun: in the vernacular the "supernatural" is a proxy for that which transcends the natural (and the laws of Nature), so this habit of speech encodes precisely the opposite meaning - that the supernatural is, in fact, unnatural. The pun emerges, however, when we hear "super-natural" - here hyphenated-with an emphasis on the first syllable: in this case, the meaning is entirely inverted-nature is itself and yet somehow also more than itself. It is this duality that Swift, and later Carlyle, so artfully inscribe in their clothes philosophy, where "man was an animal compounded of two dresses, the natural and the celestial suit" (Swift [1704] 1986, p. 37). The complete picture-the whole comprised of these two halves-as it presents itself in Carlyle, and then again in Emerson, in the latter's own particular diction, might be rendered thus: natural + supernaturalism. Here structure and skein are joined. (It cannot go unacknowledged that M. H. Abrams mapped out these territories for us a generation, or two, ago in his still magisterial Natural Supernaturalism (Abrams 1971), and before that, The Mirror and the Lamp (Abrams 1958)).

Charles Dickens remarks in American Notes for General Circulation that, by means of Sartor Resartus, "my friend Mr. Carlyle" has become the "Father in absentia" of Transcendentalism in America-and Dickens doesn't shy away from noting approvingly that "if I were a Bostonian, I think I would be a Transcendentalist." (Carlyle 2000, p. xxxi; see also Dickens in LaRocca 2013b, pp. 46-47). In broader terms, the editor of the Norman and Charlotte Strouse edition of Sartor Resartus, Roger L. Tarr, claims with bold, untroubled clarity that the book "became the inspiration for the Transcendentalist movement," indeed, that "there is no doubt whatsoever that Sartor Resartus became the foundational text of the American Transcendental Movement" (Carlyle 2000, p. xxxi). I admire the calm, assured confidence of this statement, and I hope what has been said above testifies somewhat in support of, and to the truth of, the claim; however, we want to know-and analyze-why it was such an essential agitator to an otherwise (seemingly?) homegrown American literary-philosophical-religious movement. If, as Stanley Cavell has argued, Nietzsche and his posthumous readers "gave back Emerson to the country he helped found" (see LaRocca 2017b), so it may be the case that Carlyle, a Scotsman who never set foot on American land, may have contributed to the conditions for the possibility of a special, enduring brand of American thinking. Looking then for more specifics about

13 These three chapters by Carlyle are anthologized in (LaRocca 2017a, pp. 363-76)—just ahead of Emerson's lecture "The Transcendentalist," (Emerson [1842] 2017, pp. 377-88). 
how Sartor Resartus became "the" seminal work (or perhaps, more soberly pace Tarr, among the principal works) that gave resources and reason to American Transcendentalism we can look to McSweeney and Sabor again, since they say of Sartor Resartus that "[t]he fundamental Carlylean doctrines are all articulated, or at least adumbrated," in this book, among them:

the horrors of Utilitarianism; the religious basis of society; the pattern of conversion-from the Everlasting No, through the Center of Indifference to the Everlasting Yea-which showed that, in the words of Thomas Henry Huxley, "a deep sense of religion was compatible with the entire absence of theology"; the importance of vocation-of an individual's finding his "maximum Capability"; the superiority of renunciation to the pursuit of happiness; the moral imperatives of work, duty, and reverence; the need for heroes; and the social vision that saw contemporary Britain divided into the two nations of rich and poor (Carlyle [1987] 2008, p. vii).

Again, re-reading such passages with some familiarity with Emerson's mind, mission, and methods, the resonances find their pairings—or, at least, most of them. We may require a more ample digest of remarks by Emerson to sort out his sense of the "superiority of renunciation" and the "moral imperativ[e] ... [of] reverence." Still, as a catalogue of actual (and potential) overlaps, harmonies, and affections, we can, at the least, admire the quantity -if the quality may require further study and glossing. For instance, even the final note about Britain's divided state is reflected shortly thereafter in the Panic of 1837, the ongoing antebellum crisis of chattel slavery in the United States, the Missouri Compromise, and of course, presaging the ultimate literalization of "two nations," the American Civil War. All of Emerson's major works appear between 1836 (Nature) and 1860 (The Conduct of Life), so the dualities and divisions of worlds, whether they be spiritual or terrestrial, philosophical, or for that matter literary, imagined worlds (and thus about dreaming or waking; about the perception of the moral law and the labor of enacting and embodying it), become leitmotifs of his intellectual life.

Given Tarr's propulsive claim that Carlyle's Sartor Resartus was a seminal text for the fledgling and then fulminating American Transcendentalists (and Eliot's assured estimation that "reading of Sartor Resartus was an epoch in the history" of the "minds" who encountered it (p. 311)), we could also revisit a scene from the time of Emerson's early fame (and emerging infamy among stalwart Unitarians)—in the time immediately preceding the composition of "The American Scholar" (1836)—that is more nuanced in its assessment of the lived inheritance of the volatile Scotsman and his work, namely, in this passage by Kenneth S. Sacks from Understanding Emerson (Sacks 2003):

Back in 1834 [when the last of Sartor Resartus was appearing in Fraser's], Emerson was corresponding with James Freeman Clarke, a former classmate and an emerging Transcendentalist, who obeyed the call to do Unitarian missionary work in Louisville and Cincinnati. Clarke had written an essay on Goethe and Carlyle-Emerson's intellectual signposts and the bêtes noires of more traditional Unitarians. Emerson urged him to publish it. Clarke declined, saying, "Here I am, a young man, just entering my profession ... \& my first act is to launch an arrow at a respectable senior, who has taught me much, \& treated me well ... . It would be easier to write a new article at once, \& abuse Nortonism instead of Mr. Norton."

As Sacks continues:

Reading the letters today, one might suspect that Emerson, who early on had labeled Norton a bully, was pushing Clarke forward. Clarke, however, turned the tables, perhaps unconsciously: "But why do not you write something of this kind-the review you speak of, of Carlyle's Diderot \& Sartor Resartus? (Sacks 2003, pp. 83-84).

Sacks's account is helpful on many fronts: first, in describing Carlyle (and Goethe) as "the bêtes noires of more traditional Unitarians," we glean something of the intellectual and religious frisson 
that would have been present for an establishment Unitarian-such as Clarke and Emerson-to make bold concessions to the likes of Carlyle (and Goethe), much less to imitate them (or as Clarke worried, to skewer them, as the case may be); secondly, we can see that Emerson was himself under attack by the likes of Unitarian doyens such as Andrews Norton, who would describe the young ex-minister as "the latest form of infidelity" after he delivered his Address to the Divinity School at Cambridge (Carlyle and Emerson 1883; Hodge 2003, pp. 5-6); and third, and perhaps most pertinent to our focus in this article, we see that a faithful Unitarian such as Clarke would find it natural, that is to say, intuitive, to suggest that Emerson would—should—write something about Carlyle, and especially about Sartor Resartus. Clarke's goad can be seen as at once prescient and modest, for just a couple years after the suggestion, Emerson would shepherd Carlyle's Sartor Resartus to its first American publication and provide a preface for the occasion-as such, Emerson's philosophical and religious commitments could hardly be concealed, and in fact, his allegiances were prominently declared.

Can we reach back for a moment to ask again whether Emerson's prefacing of Carlyle's text, in itself, qualifies as an act of translation-though all the words of Sartor Resartus remain intact? For Emerson is not just an emissary, but an intermediary-a figure, with speech, who stands between Carlyle's text and his (prospective) American reader. Thus, in this moment, we can invert a notion that would be familiar to bilinguistic translators, namely, that translation is a form of criticism, to our study here, where we would prefer to say that Emerson is offering criticism as form of translation (see, for example, (Bermann and Porter 2014); and earlier, (Bassnett [1980] 2014)). Monolinguistic translation may prove to be an especially fertile point of convergence for phenomena such as "cultural translation" and the work of "influence studies," since the former is addressing the moment of transfer, while the latter looks to see what sort of impression the object has made-as if one attended to the skipping stone and the other to the ripples it makes. Other moments drawn from Emerson's correspondences are especially telling on this correlation of enterprises (truly a co-relation).

Consider Emerson's letter to Benjamin Peter Hunt, whom Emerson taught at Chelmsford a decade earlier (in 1825), and later a contributor to the Dial ( $L^{14}$, vol. I, p. 432, 23 January 1835; JMN, vol. XVI, p. 112n41). Emerson asked Hunt: "What are your books? Have you fallen in with the writings of Thomas Carlyle? In Scotland eighteen months ago I sought \& made the acquaintance of this gentleman author [ ... ]. My friends think I exaggerate his merit but he seems to me one of the best, \& since Coleridge is dead, I think, the best thinker of the age. His last Essay is a series of papers in Frasers [sic.] Magazine called Sartor Resartus [ ... ]. If you have not seen it pray make inquiry after it." In his first letter to Carlyle after their first visit, about nine months hence, Emerson mixed his concern with the "grotesque teutonic apocalyptic strain of yours," in Sartor Resartus, with an appreciation of the broader implications of the work-and its author's prodigious achievement: "For are not all our circlets of will as so many little eddies rounded in by the great circle of Necessary \& could the Truth-Speaker perhaps now the best Thinker of the Saxon race, have written otherwise?" (CEC 14 May 1834, p. 16). Kenneth Marc Harris recognizes in this question “Emerson's sincere recognition of Carlyle's true powers, but also reveals a substantial growth in maturity and intellectual power in Emerson since his return from Europe" (Harris 1978, p. 11). The recognition and the growth may be attributed, in some measure, to Emerson's engagement with Carlyle—in person-and more particularly in prose, with his singular achievement, Sartor Resartus.

If the foregoing provides some ground for seeing shared (and inherited) preoccupations of theme and problem (what I have noted above under the banner of "content"), between Carlyle and Emerson, we can then take a moment to consider how the formal elements of "Carlyle's transcendentalism" found expression in the way he wrote, and thereafter the way Emerson read and transfigured certain (Carlylean) literary stylistics and philosophico-religious entitlements. I have in mind here precisely the phrase and intention characterized by George Eliot when she said the "reading of Sartor Resartus was

14 The Letters of Ralph Waldo Emerson (Emerson 1939), abbreviation $=L$. 
an epoch in the history of their minds" (Eliot 1908, p. 311). My point, in what remains, is not to say that Emerson imitated Carlyle (though such moments are bound to present themselves), rather, the more pressing observation is that Carlyle afforded Emerson the license to adapt his influences to his own purposes; in short, to become a thinker of his own accord (if indebted, as we all must be). It is in this way that we, for example, look at the chapter "Natural Supernaturalism" not a recipe for Emerson to iterate (by way of all-to-obvious imitation), but as a model from which to draw courage-not least by regarding Carlyle's own literary experiment in the context of the religious and philosophical tumult of his time, standing as Carlyle was at the crosscurrents of the Romantic and Victorian eras (In a parallel fashion, see also Gustaaf Van Cromphout's study, Emerson's Modernity and the Example of Goethe (Van Cromphout 1990)).

Robert Alter has helped us see conspicuous instances of novel writing-from Cervantes, Fielding, Diderot, and Sterne, to Nabokov - that contain or embody self-consciousness as a generic trait (one is tempted to say, genetic); moreover, as generic/genetic interact, we are encouraged to see-because of Alter's treatment-the manner in which the novel-as-such is necessarily caught up in awareness of itself. Though Carlyle does not figure in Alter's Partial Magic (Alter 1975), we can nevertheless borrow productively from Alter's description of works by the most self-conscious of writers, such as Cervantes and Sterne. "[W]ith few exceptions, there has been a lamentable lack of critical appreciation for the kind of novel that expresses its seriousness through playfulness, that is acutely aware of itself as a mere structure of words even as it tries to discover ways of going beyond words to the experiences words seek to indicate" (p. ix). Hopefully Alter's lament has been remedied by the intervening decades of criticism, or perhaps it has been taken up by another medium altogether-for example, by film - most notably the subgenre of metacinema and its champions, such as Charlie Kaufman (LaRocca 2011).

As with the novel, we are left to wonder, in the wake of Alter's account, if metacinema is not merely a subgenre but, in fact, a condition of film-as-such-a constitutive [generic/genetic] attribute that informs the medium itself. With film, of course, there is ever the potential to transcend linguistic forms (and norms, such as vernacular speech), to "discover ways of going beyond words to the experiences words seek to indicate." There seems reason to locate such an attribute-and innovation-of the film medium under the moniker "transcendental cinema" (LaRocca 2017a, p. 3); such cinema would perhaps admit a more limited reliance on words (and even on linear narrative) in favor of what some call "pure cinema" (see, as an illustration, Claire Denis's L'intrus (Denis 2004). By contrast with literary works, film has the built-in advantage (or at least difference), when practiced artfully, of showing not telling - by means of audio signals and visual images; and here, once again returned to the domain of that-which-cannot-be-perceived, we are invited to consider the ways in which an audiovisual art such as film may yet direct us to extraperceptual domains (in effect, to address what cannot be shown). Yet, as we must remain close to Carlyle's medium and his work of imaginative (literary-philosophico-religious) fiction, let us return to Alter theorizing the merits of the novel he aims to habilitate and explain:

A self-conscious novel, briefly, is a novel that systematically flaunts its own condition of artifice and that by so doing probes into the problematic relationship between real-seeming artifice and reality. I would lay equal stress on the ostentatious nature of the artifice and on the systematic operation of the flaunting. [ ... ] A fully self-conscious novel [ ... ] is one in which from beginning to end, through the style, the handling of narrative viewpoint, the names and words imposed on the characters, the patterning of the narration, the nature of the characters and what befalls them, there is a consistent effort to convey to us a sense of the fictional world as an authorial construct set up against a background of literary tradition and convention (pp. $\mathrm{x}-\mathrm{xi}$ ).

Though, again, Alter has in mind Cervantes, et al., it seems abundantly evident-a veritable chorus of critical reading has reached consensus on the matter-that Sartor Resartus deserves full membership in this club. So our question evolves yet again: in what way does this attribute of Carlyle's work intersect with Emerson's production of literary and philosophical work, and his religious outlook more generally—what we have alluded to as a "retailoring" of Emerson's Unitarian religious commitments? 
From as early as Nature, we are in the company of a writer who is morosely nostalgic about a lost connection to the divine ("The foregoing generations beheld God and nature face to face; we, through their eyes."). Part of the "retailoring" of Unitarian religious commitments, as I am calling them, has to do with Emerson's debate-both internal and expressed (as in his "The Lord's Supper") about the relationship between the form and the content authorship undertakes to create. For instance, what does the form of the sermon offer or constrain when placed beside the essay? Who is the audience for one work, and then the other? From our vantage, we can, of course, follow Emerson's transition from the clerical lectern to the public lecture hall, but we are left to wonder in what measure Carlylean metafiction contributed to his capacity to believe the essay (or related [secular] forms, such as the lecture and the address) might be a better fit for his intellectual ambitions. For instance, to some readers, it may seem just as plausible (perhaps more so) that Emerson's meta-stance with regard to religion, revelation, and related matters has more to do with the influence of Montaigne; unlike Carlyle, Emerson does not engage in antic myth-making only to call attention to its fictional status. If subject matter (theme, concept, philosophical and religious query) is understood as "content," then Emerson and Carlyle may have many points of overlap, yet, stylistically-in what we may think of as tone or temperament-they are regularly far apart, and indeed, on many occasions, desperately at odds. On the matter of tone or temperament, the present investigation seems to send us back further, to Montaigne.

Yet, since our present appointment is with Carlyle, let us begin (anew) by looking (afresh) at the kind of writing Emerson is most famous for: his essays. Much of the content of the essays derives directly —in some cases verbatim — from journal entries; in other cases, Emerson would lecture (repeatedly) on a topic and refine his prose until it would transition from "lecture" to "essay." This is a kind of macro view of the operation. And from such a vantage what kind of work should we call Emerson's essays? Are they fiction or nonfiction? Poetic declamation or mystical conjuring? Stoic enchiridion or Plotinian metaphysics? Journalism or journaling? Travelogue or social science? Mystical self-help manual or anthropological report? Cultural criticism or political critique? Prophetic religious oracle or philosophical excursus? - Standing in need of a reply, this is precisely the moment when the lessons of Carlyle's innovations (-his integration and adaptation of multiple traditions in Sartor Resartus) provide a model for Emerson to assume, or at the very least, to creatively contend with-in short, to transform (as part of a project that sees criticism as translation). In short, Emerson does not have to answer these questions; instead he can, as the spirit and occasion present themselves, assume them all as his rightful purview and province. I do not think it too much to describe this assumption of literary power as a kind of "flaunting" (to borrow Alter's word).

Consider, for example, the way Emerson reads the issue of authorship as it relates to Plato. "Great geniuses have the shortest biographies. [...] They lived in their writings [ ... ]. Plato, especially, has no external biography. If he had lover, wife, or children, we hear nothing of them. He ground them all into paint. As a good chimney burns its smoke, so a philosopher converts the value of all his fortunes into his intellectual performances" ("Plato; or, the Philosopher"). Emerson-though he wrote voluminous journals, letters, lectures informed by travel, political speeches, and has myriad, length biographies written about his life and work-may still qualify for these traits attributed to Plato. Page after page of published essays, for example, admit of their "sources" in the everyday-from observations made while reading, farming, playing with his children, taking a long walk, speaking with contemporaries of every station. Emerson names cities and towns he has visited. Emerson quotes from the books he read while traveling. The essays become, after a fashion, a document that involves the elements of their making (perhaps in a way akin to Jean-Luc Godard, who said every film is a documentary of its actors, or Jacques Rivette, who said every film is a documentary of its own making) (Lim 2010). And thus, necessarily, Emerson must be aware-self-conscious, in fact-of this integration and transformation of factual elements, how he actively "converts the value of all his fortunes into his intellectual performances." A significant part of Emerson's art lies in his capacity to make the particular into the general, to poetize the details of everyday experience so they might rise to the level 
of transcendental insight. (We could as well turn to Thomas Hardy's "Wessex" as a model of such poetizing - putting the details of his own life, say, in Oxford, to the dramatic purposes of Jude Fawley's desperate desire to become a scholar at Christminster (Hardy [1896] 1981)).

Formally, we see kindred things happening in Sartor Resartus—only Carlyle pushes his authorship into the realm of imaginative fiction (and decidedly joins the ranks of self-conscious fiction), for, by among other things, inventing an English editor and the character of Diogenes Teufelsdröckh. Though Emerson resists the lure and promise of writing fiction (does he ever even write a short story? I don't think so, at least, nothing in his maturity), he allows for ways in which his self-consciousness participates in his identity as a writer. In this way, "Emerson" is a persona, the name of Emerson's editor and protagonist, the essays are the fruits of their labors. And since Emerson is aware that $w e$, as his readers, are (made) aware of his labors, the reflexivity of Emerson's writing recurrently presents itself. Of course, by mentioning what appear to be biographical facts, Emerson may confuse (or lure) some readers into thinking that those "facts"—and everything that surrounds them-are to be read at face value. Yet, as McSweeney and Sabor say about Sartor Resartus, we could say of Emerson's work: the "text is continually challenging the reader's expectations and competence. The key feature of Carlyle's modus operandi is that the text is about both itself and the experience of reading it" (Carlyle [1987] 2008, p. xix). Like Sartor Resartus, we can find contained in Emerson's work "its own commentary," how it "has within itself a fully developed model of a reader grappling with a difficult text." Sartor Resartus, in this respect, is easier to read than Emerson's prose because the "description of Professor Diogenes Teufelsdröckh's strange book on clothes [ ... ] is at the same time a pointed description of the very book that the reader of Sartor Resartus holds in his hands" (Carlyle [1987] 2008, p. xix); in short, we have company when reading Teufelsdröckh. Not so when reading Emerson. By contrast, the self-consciousness of Emerson's essays, we might say, is already digested into the prose itself, and thus is less apparent, less forthcoming. Like Montaigne before him and Nietzsche after him, the meta-referential qualities of the text are part and parcel of its being. Not incidentally, the essayistic and aphoristic writers become the harder to decipher because of the legerdemain that obscures their distance from the reality (or "personal" nature) of the prose. Let me say more on this last point.

We might defensibly read Emerson's letters and journals as works of nonfiction, and yet, even there-given his attention to the project and his assiduous, decades-long creation of it—posterity must have been close in mind. Yet, when those and related experiences had been "ground into paint" - in the works we know as the lectures, addresses, and essays-I think we must withdraw from presuming easy isomorphism of their authorship and the historical Emerson. When we read in "Experience," "Grief too will make us idealists. In the death of my son, now more than two years ago, I seem to have lost a beautiful estate,-no more. I cannot get it nearer to me" ("Experience"), we are forgiven for welcoming the grieving father, and thus situating that "I" and the "my" as Emerson's own, as was his son. The passage has received understandably thorough attention (from Cavell (2003) to Cameron (2007), among others (see LaRocca 2013b, pp. 10-13)). Even if we are not familiar with the "I" of Emerson's voluminous journals and epistolary productions, we might be forgiven for reading it on this occasion as a kind of journal entry or bit of documentary confession. And yet, this scene, like so many others seems precisely to be written in a mode of studied distanciation-not to effect coolness or indifference (say to the existence of evil or the pain of a child's death preceding a parent's)—but instead as aimed for the aspiration of universal truth: "Grief too will make us idealists," with italics added. Emerson is addressing what might be regarded as one of the most real things a person can experience (viz., the death of the child)-little else can seem as real or as vexing. And yet, even as he admits that his own child has died, his point is not meant to stop at the valence of his private suffering, but instead to radiate to the perplexing generality that even this kind of reality does not make us-any of us-realists. This scene is Emerson's meta-referential induction at its finest: draw a scene from a moment of private history and provide a context in which it gains broad philosophical merit (a status worthy of religiously-minded consideration). Thus, when it comes time to discern the implications 
of the "it"—viz., the "beautiful estate" - (I cannot get it nearer to me."), we are left to ponder the mystery on our own and collectively, with Emerson and well beyond him, centuries later, and one presumes ever more. Recapturing a line from Reynolds: Emerson, like Carlyle, could be said to have "disarmed grotesque images by converting them into figures of higher truths" (502); and recall how McSweeney and Sabor related Carlyle's conviction that prose fiction was "superior to history for the revelation of truth" (Carlyle [1987] 2008, p. x). Yes, we can trace a direct link to say that the historical Emerson suffered the death of his son, Waldo; but that personal calamity is not the point of this passage in "Experience" - rather, we are meant to see what can be perceived by us because of its occurrence. Surely, it would be odd if we, as readers, grieved for Emerson's child (as father grieved for son), but it is not odd at all to grieve with him, that is, for our beautiful estate (and its fragility in ourselves and those whom we love as dearly—and have lost, or fear losing).

These claims of formal affiliation (indeed, given all this talk of parents and children, filiation) - and so we might add intellectual progeny as well as authorial validation-from Carlyle to Emerson, as noted above, attempt to account for one side of the potential impact felt by the American acolyte from his Scottish mentor. But we can pick up the other side of this dyad, the nature of content, and work our way systematically through a series of prominent and compelling examples. Such an inductive method is inexhaustible, so, in the few cases adduced below, I am aiming for salience and representativeness.

In the chapter "Symbols," we hear Professor Teufelsdröckh say:

In the Symbol [ ... ] there is every, more or less distinctly and directly, some embodiment and revelation of the Infinite; the Infinite is made to blend with the Finite, to stand visible, and as it were attainable there. By Symbols, accordingly, is man guided and commanded, made happy, made wretched. He every where finds himself encompassed with Symbols, recognized as such or not recognized: the Universe is but one vast Symbol of God; nay, if thou wilt have it, what is man himself but a Symbol of God, is not all that he does symbolical; a revelation to Sense of the mystic god-given Force that is in him [ ... ]. Not a Hut he builds but is the visible embodiment of a Thought; but bears visible record of invisible things; but is, in the transcendental sense, symbolical as well as real (LaRocca 2017a, p. 367).

Thus, as Teufelsdröckh helps us distill the above into the notion that "It is in and through Symbols that man, consciously or unconsciously, lives, works, and has his being," so we find Emerson, in the years immediately following the publication of Sartor Resartus, a remark in his first book Nature how "Nature is the symbol of spirit."; "Every natural fact is a symbol of some spiritual fact."; "[A]ll spiritual facts are represented by natural symbols."; "A man's power to connect his thought with its proper symbol (CW, vol. I, pp. 25-26, 29). And we can skim to two-plus decades later, in 1859, to a lecture entitled "Art and Criticism," in which the following things are said after a series of praise-filled homilies to Carlyle: "Idealism regards the world as symbolic, and all these symbols or forms as fugitive and convertible expressions. The power of the poet is in controlling these symbols; in using every fact in Nature, however great and stable, as a fluent symbol, and in measuring his strength by the facility with which he makes the mood of mind give its color to things (CW, "Natural History of Intellect," vol. XII, p. 300). In the essay, "The Poet" (1844), Emerson expounds at length on how "[w]e are symbols and inhabit symbols" (CW, vol. III, p. 20); In "Poetry and Imagination," a variorum of "The Poet," Emerson continued, now in 1872, to lecture on the topic: "The poet discovers that what men value as substances have higher value as symbols" (CW, vol. VIII, p. 23).

\section{Conclusions: Emerson's Late Encomium for his Early Exemplar}

The collection, collation, and juxtaposition of passages just above may serve well Emerson's observation: "how much finer things are in composition than alone" (LaRocca 2013a, pp. 74, 130, 142, $152,253)$. I could go on, of course, as there are hundreds of such assemblages of Carlyle's and Emerson's prose (as instantiated tersely in the foregoing) that could be curated and mounted ("Tis wise in man to 
make Cabinets" is the line that follows the one just quoted), and yet, one can hope that a sufficiently pronounced case study will provide credibility to the claim that Emerson, in significant measure, draws from Carlyle—especially from Sartor Resartus—not just a vocabulary that he will carry with him from first to last, but an orientation to metaphysical positions that will form and inform and transform his translation of Unitarian ideas into the language of Transcendentalism. In his journal, Emerson inscribed a line from Sartor Resartus_-"Method is union of like with like" (from Bk I, Ch. XI), and below made his own commentary: "Classification is delight" (JMN, "Encyclopedia," vol VI. (1824-1838), p. 22). Emerson finds in Carlyle, therefore, not only a lexicon, but also a syntax. In a chapter from Sartor Resartus entitled "Centre of Indifference," we learned that we, individually, have become a "fixed centre to revolve round" (Carlyle 2000, p. 127). In Emerson's lecture "The Transcendentalist," delivered in December 1841, he says of the idealist: "His experience inclines him to behold the procession of facts you call the world, as flowing perpetually outward from an invisible, unsounded centre in himself, centre alike of him and of them, and necessitating him to regard all things as having a subjective or relative existence, relative to that aforesaid Unknown Centre of him" (LaRocca 2017a, p. 379). Such conceptual translations recur regularly, page after page, year after year, decade after decade. And why not, as Carlyle's Professor Teufelsdröckh baldly states: "the Philosophy of Clothes attains to Transcendentalism" (Carlyle 2000, p. 187).

Should we wish to accumulate some sense of Emerson's direct—say, biographical—impressions of Carlyle, we can look to English Traits, especially the first chapter entitled "First Visit to England," (when Emerson visited Carlyle in Scotland, July 1833), and the sixteenth chapter, "Stonehenge," the latter of which offers a diary-like reminiscence of Emerson's second visit with Carlyle in June 1848 as they perambulate the Neolithic site (see LaRocca 2013a, pp. 36, 59, 102). In February 1881, shortly following Carlyle's death, and only fourteen months from his own death, Emerson gathered materials from his personal correspondence and journals (mostly from 1848) and gave a public eulogy. If the sentences themselves emerged from Emerson in his prime (a good time to make their appearance, since they would be representative of Emerson's contemporaneous life with Carlyle, and at the height of Emerson's powers), their selection for this occasion, three decades later, offers both a testimony and ratification of the deeper lines of relation connecting the two thinkers (their disparate and sometimes allergic reaction to each other's opposing temperaments notwithstanding). Or as their relationship has been described: they were "not always in agreement, but always in sympathy" (Carlyle 2000, p. xxxi). But then the exclusive "always" puts a lot of (perhaps too much) pressure on the meaning of "sympathy," since we know, as mentioned, that Emerson was especially impatient with many of Carlyle's social, political, and racial commitments. If by "sympathy," though, we have in mind something like a style of speech, or a vigor for eschewing posturing and ossified presumptions, especially of the elites, then we may rest easier with the kind of relationship—or proximity—-the two men shared. Thus, when calling to mind Nietzsche, who later "philosophized with a hammer," it feels fitting that Emerson says of Carlyle: "So this man is a hammer that crushes mediocrity and pretension. He detects weakness on the instant, and touches it. He has a vivacious, aggressive temperament, and unimpressionable" (CW, vol. X, p. 493). Perhaps we should say that if Emerson did not, himself, behave this way, he nevertheless admired the power and perspicacious judgment such a mind offers up to us. Contrast his praise of Carlyle with the the Emerson who confided, demurely, in "Self-Reliance" that "[e]very decent and well-spoken individual affects and sways me more than is right." As readers looking for Emerson's integration—indeed, digestion—of Carlyle's ideas and outlooks, especially as embodied in Sartor Resartus, such biographical observations may seem ancillary, and yet they convey something of the spirit in which Carlyle wrote, and that attracted Emerson in the first place-and over the course of his intellectual life. Yet, as we keep pace with such attraction, we should hold close the caution and criticism Emerson exhibited for his mentor; admiration may lie very far from imitation, emulation, or even the invention of one's own brand of the same. Thus, as we are here more intrigued by tracing lines of "sympathy" (i.e., of attraction and compatibility in so far as they are instructive and inspiring as opposed to proscriptive), we can think, for example, of what Emerson has to say 
about self-reliance, Man Thinking, the "office of the scholar," and "the poet's fidelity to his office," ("The American Scholar," "The Poet"), and listen to Emerson's account of Carlyle's facilities, ambitions, and effects:

Combined with this warfare on respectabilities, and, indeed, pointing all his satire, is the severity of his moral sentiment. In proportion to the peals of laughter amid which he strips the plumes of a pretender and shows the lean hypocrisy to every vantage of ridicule, does he worship whatever enthusiasm, fortitude, love or other sign of a good nature is in a man. There is nothing deeper in his constitution than his humor, than the considerate, condescending good nature with which he looks at every object in existence, as a man might look at a mouse. [ ... ]

His guiding genius is his moral sense, his perception of the sole importance of truth and justice; but that is a truth of character, not of catechisms (CW, vol. X, p. 495).

In his first reading in Sartor Resartus, marked by a journal entry in 1833, Emerson notes: "As to Carlyle, he is an exemplification of Novalis's maxim concerning the union of Poetry and Philosophy. He has married them, and both are the gainers. Who has done so before as truly and as well? Sartor Resartus is a philosophical poem" (JMN, vol. IV, Notebook A [1834], p. 302). The praise is itself a re-statement of Carlyle's distress at our false dichotomy, as he writes in "Novalis"15 (Carlyle 1899, p. 41.): "The division of Philosopher and Poet is only apparent, and to the disadvantage of both. It is a sign of disease, and of a sickly constitution." Emerson's perpetual equivocation between "the poet" and "the seer" and "the philosopher" (e.g., in the essay "The Poet") adds yet another way in which he took Carlyle's claims to heart, magnified them, and augmented them for his own purposes. Again, for Emerson, literary and philosophical criticism becomes a form of translation.

Yet perhaps the most emblematic statement of Emerson's respect for Carlyle as a thinker comes from the early scene in which the acolyte suddenly becomes the shepherd for the master's masterwork. In 1836, Emerson made a connection with the publisher James Munroe in Boston that culminated in Sartor Resartus's debut in America and its first time anywhere as a unified book-and featuring a preface by Emerson. We can marvel how in just three years Emerson went from anonymous New Englander at Carlyle's door-step in remote Dumfrieshire to the emcee announcing the Scottish essayist's arrival on American shores, his fictive professor Teufelsdröckh, and the particular, peculiar kind of writing Sartor Resartus presents and represents. Drawing from the language of "the great Dissector of Melancholy," Robert Burton, and his era, Emerson wastes no time in commenting simultaneously about the content of the book and the character of its author, and in the process cultivating a series of fecund puns: "It is his humor to advance the gravest speculations upon the gravest topics in a quaint and burlesque style" (Carlyle 1836, p. 3; Hardy [1896] 1981, p. 473). In this "work of imagination," which he commends to readers, Emerson underscores his faith in the uniqueness (and unique power) of Sartor Resartus: "We believe, no book has been published for many years, written in a more sincere style of idiomatic English, or which discovers an equal mastery over all the riches of the language. The author makes ample amends for the occasional eccentricity of his genius, not only by frequent bursts of pure splendor, but by the wit and sense which never fail him" (Carlyle 1836, pp. 3-4).

We have become familiar with the point in "Circles" where Emerson cautions "[b]eware when the great God lets loose a thinker on this planet. Then all things are at risk." But this phrase appeared years before "Circles" when Emerson was speaking about Carlyle: in him "a new thinker had been let loose upon the planet" (Froude 1884, vol. III, p. 246). The novelty of Carlyle's thinking, we can now say, lay, in part in the way, in his writing, he adopted forms, styles, tropes, and techniques familiar to the novel and made them available to a generation of religiously agitated Americans, Emerson principal among

15 "Novalis", originally published in The Foreign Review and Critical Miscellany [1829], and later included in Critical and Miscellaneous Essays, 1899. 
them. Drawing from a rich tradition of metafiction-from Cervantes to Defoe to Fielding, from Swift to Sterne-Carlyle provided to Emerson and his generation a scintillating model of what is possible when literature, philosophy, and religious thinking become available to one another. Doubtless, this is a tradition of transdisciplinary bravado and intellectual cross-pollination that we may still benefit from studying ... and enacting.

Conflicts of Interest: The author declares no conflicts of interest.

\section{References}

Abrams, Meyer Howard. 1958. The Mirror and the Lamp: Romantic Theory and the Critical Tradition. New York: Norton. Abrams, Meyer Howard. 1971. Natural Supernaturalism: Tradition and Revolution in Romantic Literature. New York: Norton. Alter, Robert. 1975. Partial Magic: The Novel as Self-Conscious Genre. Berkeley: The University of California Press. Anderson, Amanda. 2017. Political Psychology: Theory and Doxa. Lecture presented at The School of Criticism and Theory, Cornell University, Ithaca, NY, USA, July 17.

Apter, Emily. 2013. Against World Literature: On the Politics of Untranslatability. New York: Verso.

Apter, Emily. 2015. Lexilalia: On Translating a Dictionary of Untranslatable Philosophical Terms. Paragraph 38: 159-73. [CrossRef]

Apter, Emily. 2017. Untranslatibility, 'Theory,' and the World Literature Debate. Paper presented at a colloquium convened at The School of Criticism and Theory, Cornell University, Ithaca, NY, USA, July 20.

Arnold, Matthew. 1895. The Function of Criticism at the Present Time. New York: Macmillan and Company.

Bassnett, Susan. 2014. Translation Studies, 4th ed. New York: Routledge. First published 1980.

Bermann, Sanda, and Catherine Porter. 2014. A Companion to Translation Studies. London: Wiley Blackwell.

Bloom, Harold. 1975. A Map of Misreading. Oxford: Oxford University Press.

Buell, Lawrence. 2003. Emerson. Cambridge: The Belknap Press of Harvard University Press.

Cameron, Sharon. 2007. Impersonality: Seven Essays. Chicago: The University of Chicago Press.

Carlyle, Thomas. 1976. Thomas Carlyle: Early Letters. Edited by Charles Eliot Norton. Hildesheim: Georg Olms Verlag. First published 1886.

Carlyle, Thomas. 1899. Novalis. London: Chapman and Hall, vol. II. First published 1829.

Carlyle, Thomas. 2008. Sartor Resartus. Edited by Kerry McSweeney and Peter Sabor. Oxford: Oxford University Press. First published 1987.

Carlyle, Thomas. 1836. Sartor Resartus. Preface by Ralph Waldo Emerson; Philadelphia: James Munroe and Company.

Carlyle, Thomas. 1904. Critical and Miscellaneous Essays, Centenary ed. Edited by Henry Duff Traill. New York: Charles Scribner's Sons, vol. I.

Carlyle, Thomas. 2000. Sartor Resartus: The Life and Opinions of Herr Teufelsdröckh in Three Books. The Norman and Charlotte Strouse Edition of the Writings of Thomas Carlyle. Berkeley: University of California Press.

Carlyle, Thomas, and Jane Welsh Carlyle. 1970. The Collected Letters of Thomas Carlyle and Jane Walsh Carlyle. Edited by Charles Richard Sanders, Kenneth J. Fielding and Clyde de L. Ryals. Durham: Duke University Press.

Carlyle, Thomas, and Ralph Waldo Emerson. 1883. The Correspondence of Thomas Carlyle and Ralph Waldo Emerson, 1834-1872. Edited by Charles Eliot Norton. Boston: James R. Osgood and Company.

Cassin, Barbara. 2010. Philosophizing in Languages. Nottingham French Studies 49: 17-28. [CrossRef]

Cassin, Barbara, Emily Apter, Jacques Lezra, and Michael Wood. 2014. Dictionary of Untranslatables: A Philosophical Lexicon. Princeton: Princeton University Press.

Cavell, Stanley. 2003. Emerson's Transcendental Etudes. Edited by David Justin Hodge. Stanford: Stanford University Press.

Cunningham, M. Allen. 2016. Funny-Ass Thoreau. Portland: Atelier26 Books.

Denis, Claire, dir. 2004. L'Intrus (The Intruder). Paris: Ognon Pictures, et al.

Derrida, Jacques. 2002. "Ants [Fourmis]" in Reading Cixous Writing. The Oxford Literary Review 24: 17-42. First presented in 1990, and later published in 1994. Lectures de la Différence Sexuelle. Paris: Des femmes.

Descola, Phillipe. 2013. Beyond Nature and Culture. Chicago: The University of Chicago Press.

Eliot, George. 1908. The Writings of George Eliot: Essays and Uncollected Papers. Boston: Houghton Mifflin Company, vol. XXII. 
Emerson, Ralph Waldo. 1903-1904. The Complete Works of Ralph Waldo Emerson, concord ed. Boston: Houghton, Mifflin and Company.

Emerson, Ralph Waldo. 1939. The Letters of Ralph Waldo Emerson. Edited by Ralph Rusk. New York: Columbia University Press.

Emerson, Ralph Waldo. 1960. The Journals and Miscellaneous Notebooks of Ralph Waldo Emerson. Edited by William H. Gilman and et al. Cambridge: Harvard University Press.

Emerson, Ralph Waldo. 1983. Essays and Lectures. Edited by Joel Porte. New York: The Library of America.

Emerson, Ralph Waldo. 2017. The Transcendentalist. In The Bloomsbury Anthology of Transcendental Thought: From Antiquity to the Anthropocene. Edited by David LaRocca. New York: Bloomsbury. First published 1842.

Froude, James. 1884. Thomas Carlyle: A History of His Life in London, 1834-1881. New York: Charles Scribner's Sons, vol. III.

Habich, Robert D. 2015. An 'Extempore Adventurer' in Italy: Emerson as International Tourist. In A Power to Translate the World: New Essays on Emerson and International Culture. Edited by David LaRocca and Ricardo Miguel-Alfonso. Hanover: Dartmouth College Press.

Hardy, Thomas. 1981. Jude the Obscure. New York: Penguin. First published 1896.

Harris, Kenneth Marc. 1978. Carlyle and Emerson: Their Long Debate. Cambridge: Harvard University Press.

Heffer, Simon. 1995. Moral Desperado: A Life of Thomas Carlyle. London: Weidenfeld and Nicolson.

Hodge, David Justin. 2003. On Emerson. Belmont: Wadsworth.

Hodge, David Justin. 2005. Una Traduzione Transatlantica: Fato e Libertà in Emerson a nel giovane Nietzsche [Transatlantic Translation: Young Nietzsche Writing Toward Emerson]. In Nietzsche e L'America. Edited by Sergio Franzese. Pisa: Edizioni ETS, Nietzsceana Saggi 2.

Hofstadter, Douglas, and Emmanuel Sander. 2013. Surfaces and Essences: Analogy as the Fuel and Fire of Thinking. New York: Basic Books.

Koch, Daniel. 2012. Ralph Waldo Emerson in Europe: Class, Race, and Revolution in the Making of an American Thinker. London: I.B. Tauris.

LaRocca, David. 2011. The Philosophy of Charlie Kaufman. Lexington: The University Press of Kentucky.

LaRocca, David. 2013a. Emerson's English Traits and the Natural History of Metaphor. New York: Bloomsbury.

LaRocca, David. 2013b. Estimating Emerson: An Anthology of Criticism from Carlyle to Cavell. New York: Bloomsbury.

LaRocca, David. 2015b. A New Philosophy of Clothes: Brunello Cucinelli's Neohumanistic Business Ethics. Journal of Religion and Business Ethic 3: article 10.

LaRocca, David. 2015c. Brunello Cucinelli: A Humanistic Approach to Luxury, Philanthropy, and Stewardship. Journal of Religion and Business Ethics 3: article 9.

LaRocca, David, ed. 2017a. The Bloomsbury Anthology of Transcendental Thought: From Antiquity to the Anthropocene. New York: Bloomsbury.

LaRocca, David. 2017b. Emerson Recomposed: Emerson's Uses of His American 'Soul-Brother'. In Nietzsche and the Philosophers. Edited by Mark T. Conard. London: Routledge.

LaRocca, David, and Ricardo Miguel-Alfonso, eds. 2015. A Power to Translate the World: New Essays on Emerson and International Culture. Hanover: Dartmouth College Press.

Lim, Dennis. 2010. It's Actual Life. No, It's Drama. No, It's Both. The New York Times, August 20. Available online: http:/ / www.nytimes.com/2010/08/22/movies/22hybrid.html (accessed on 26 May 2017).

Matterson, Stephen. 2014. Melville: Fashioning Modernity. New York: Bloomsbury.

Nancy, Jean-Luc. 2008. Corpus. Translated by Richard A. Rand. New York: Fordham University Press.

Packer, Barbara L. 2007. The Transcendentalists. Athens: University of Georgia Press.

Pappas, Nickolas. 2016. The Philosopher's New Clothes: The Theaetetus, the Academy, and Philosophy's Turn against Fashion. New York: Routledge.

Punter, David. 2007. Metaphor. New York: Routledge.

Reynolds, David S. 1988. Beneath the American Renaissance: The Subversive Imagination in the Age of Emerson and Melville. Oxford: Oxford University Press.

Richardson, Robert D. 1995. Emerson: The Mind on Fire: A Biography. Berkeley: The University of California Press.

Sacks, Kenneth S. 2003. Understanding Emerson: "The American Scholar" and His Struggle for Self-Reliance. Princeton: Princeton University Press.

Schulz, Kathryn. 2010. Being Wrong: Adventures at the Margin of Error. New York: Harper Collins. 
Schulz, Kathryn. 2011. On Being Wrong. TED.com, March. Available online: https://www.ted.com/talks/ kathryn_schulz_on_being_wrong/transcript (accessed on 26 May 2017).

Schulz, Kathryn. 2015. Pond Scum: Henry David Thoreau's Moral Myopia. The New Yorker, October 19.

Swift, Jonathan. 1986. A Tale of a Tub and Other Works. Edited by Angus Ross and David Woolley. Oxford: Oxford University Press. First published 1704.

Tennyson, Georg Bernhard. 1965. Sartor Called Resartus: The Genesis, Structure, and Style of Thomas Carlyle's First Major Work. Princeton: Princeton University Press.

Thoreau, Henry David. 1991. Walden; or, Life in the Woods. New York: The Library of America. First published 1854. Van Cromphout, Gustaaf. 1990. Emerson's Modernity and the Example of Goethe. Columbia: University of Missouri Press. 